\title{
ELEMENTS OF EFFECTIVE NUTRITION EDUCATION FOR ADULTS WITH DIABETES MELLITUS IN RESOURCE-POOR SETTINGS: A REVIEW
}

\author{
Authors: \\ Jane W. Muchiri ${ }^{1}$ \\ Gerda Gericke \\ Paul Rheeder ${ }^{2}$

\begin{abstract}
Affiliations:
${ }^{1}$ Department of Human

Nutrition, University of

Pretoria, South Africa

${ }^{2}$ Division of Clinical

Epidemiology, University

of Pretoria, South Africa
\end{abstract}

\section{Correspondence to:}

Jane W. Muchiri

e-mail:

jane.muchiri@up.ac.za

\section{Postal address:}

Department of Human

Nutrition, Faculty of

Health Sciences, 4-6 HW

Snyman South Building,

University of Pretoria,

PO Box 667, Pretoria 0001,

South Africa

\section{Keywords:}

type 2 diabetes; low-

income; nutrition

education; effectiveness;

self-management

education

\section{Dates:}

Received: 14 July 2008

Accepted: 26 Nov. 2008

Published: 27 May 2009

How to cite this article:

Muchiri, J.W., Gericke,

G. \& Rheeder, P., 2009,

'Elements of effective

nutrition education for

adults with diabetes

mellitus in resource-poor

settings: A review', Health

SA Gesondheid 14(1), 9

pages. Art. \#413, DOI:

10.4102/hsag.v14i1.413

This article is available

at:

http://www.hsag.co.za

(C) 2009. The Authors. Licensee: OpenJournals

Publishing. This work

is licensed under the

Creative Commons

Attribution License.

\section{ABSTRACT}

This review article highlights the key factors that need consideration in planning an effective nutrition education programme for adults with type 2 diabetes mellitus in resource-poor settings.

Type 2 diabetes is increasing to epidemic levels globally. Low socio-economic status is associated with poorer health outcomes and a higher economic burden. Individuals with diabetes cite dietary adherence as the most difficult self-care area. Effective nutrition education achieves the desired goals and outcomes, which include appropriate change in dietary behaviour, improved glycaemic control, plasma lipid levels, blood pressure and body weight, as well as improved potential mediators (knowledge, skills and attitudes). Elements that contribute to a successful nutrition education programme include interventions tailored to the needs, abilities and socio-cultural context of the target group, the active involvement of the patient, a behaviour-focused approach based on appropriate theory, suitable delivery methods and individual/group approaches. Adequate contact time with an educator (> 10 hours), the educator's competence, provision of social support and follow-up intervention are also crucial.

Effectively educating diabetic individuals from resource-poor settings in nutrition is a challenging task. It needs innovative and skilled educators who are sensitive to the unique needs of the target group and who use appropriate approaches to address these needs.

\section{OPSOMMING}

Hierdie artikel beklemtoon die sleutelfaktore wat in oorweging geneem moet word wanneer 'n effektiewe voedingsopleidingprogram vir volwassenes met tipe 2-diabetes uit hulpbron-arm agtergronde beplan word.

Tipe 2-diabetes is besig om globaal tot epidemiese vlakke toe te neem. Lae sosio-ekonomiese status word geassosieer met swakker gesondheidsresultate en 'n hoër ekonomiese las. Dieetnakoming word deur persone met diabetes as die moeilikste selfversorgingsgebied uitgewys.

Doeltreffende voedingsopleiding bereik die gewenste doelwitte en resultate wat toepaslike veranderings in dieetgedrag, verbeterde glisemiese beheer, verbeterde bloedlipiede, bloeddruk en liggaams-gewig, en verbeterde potensiële bemiddelaars (kennis, vaardighede en houdings), insluit. Elemente wat tot 'n suksesvolle voedingsopleidingprogram bydra, sluit ingrypings in wat geskoei is op die behoeftes, vaardighede en sosiaal-kulturele konteks van die teikengroep, aktiewe betrekking van die pasient, gebruik van 'n benadering wat ingestel is op gedrag en gegrond is op toepaslike teorie, toepaslike metodes van aflewering en individuele/groepbenaderings, geskikte duur en kontaktyd (> 10 uur), een wat vir sosiale ondersteuning en opvolgintervensie sorg, en deur 'n bedrewe verskaffer bemiddel word.

Om diabetiese individue uit hulpbron-arm agtergronde op te lei in voeding is ' $n$ uitdagende taak wat vindingryke en bedrewe opvoeders verg. Hierdie opvoeders moet sensitief wees vir die unieke behoeftes van die teikengroep en toepaslike benaderings volg om genoemde behoeftes aan te spreek.

\section{INTRODUCTION}

The prevalence of diabetes is increasing globally to such high levels that it is being referred to as 'an epidemic' (Wang et al. 2005:174; Wild et al. 2004:1047). Diabetes is a complex disease associated with considerable morbidity, mortality and loss of quality of life (Narayan et al. 2000:78). Diabetes places a significant economic burden on health care systems and individuals suffering from the condition (Narayan et al. 2000:79; Ramachadran et al. 2007:252). Groups with a low socio-economic status tend to bear the brunt of this burden, as they spend a higher proportion of the family's income on diabetes care (Narayan et al. 2000:79; Ramachadran et al. 2007:255). They have also been noted to be among those with poor long-term diabetic outcomes (Bell et al. 2001:128; Chin, Zhang \& Merrell 1998:1091; Roper et al. 2001:1389) and poor glycaemic control (Levetan, Levitt \& Bonnici 1997:368). It is therefore critical that special attention, as well as feasible and effective diabetes management strategies, be directed specifically at populations in resource-poor settings.

Patient education, also referred to as diabetes self-management education (DSME), is a cornerstone of treatment for diabetes (ADA 2007a:30). Diabetes education is the process of providing the diabetic with the knowledge, skills and motivation that are needed to perform self-care, manage crises and make the lifestyle changes required to successfully manage their condition (Clement 1995:18). An extensive body of literature exists that demonstrates that DSME significantly improves health outcomes (Asha, Pradeepa \& Mohan 2004:101; Ellis et al. 2004:103; Norris, Engelgau \& Narayan 2001:561; Norris et al. 2002:1159; Warsi et al. 2004:1647).

Medical nutrition therapy (MNT) is an integral component of diabetes treatment and self-management education (ADA 2007:30). MNT, both as an independent variable and in combination with other 
components of DSME, has been shown to be effective in improving health outcomes (Pastors et al. 2002:609; Pastors et al. 2003:828). MNT can prevent or postpone the onset or slow the progression of costly complications of diabetes. In non-insulin dependent diabetes there is potential for cost savings through decreasing or discontinuing the use of oral hypoglycaemic agents when diet and exercise alone can provide the desired outcomes (Gagliardino \& Ectchegoyen 2001:1005; Hampton, Bodansky \& Stickland 1998:166; PADA 1995:89). MNT has also been shown to produce similar outcomes to those of oral glucose medication alone (Franz et al. 2003:30).

Nutrition education (NE), an element of MNT, is defined as any set of learning experiences designed to facilitate the voluntary adoption of eating and other nutrition-related behaviours conducive to health and well-being (PADA 1996:1183). NE assists in improving an individual's nutrition knowledge, modifying his/her eating behaviour and improving physiological outcomes (Franz et al. 1995:95; Glasgow, Toobert \& Hampson 1996:19; Glasgow et al. 1997:32; Shabbidar, Fathi \& Shirazifard 2006:156). The latter include blood glucose and haemoglobin $\mathrm{A}_{1 \mathrm{c}}\left(\mathrm{HbA}_{1 \mathrm{c}}\right)$ (Franz et al. 1995:1013-1014; Lemon et al. 2004:1810; Miller et al. 2002:256; Wilson et al. 2003:26), blood lipids, blood pressure and body weight (Franz et al. 1995:1013-1014; Lemon et al. 2004:1810).

Despite the established role of MNT in enhancing diabetes control, many individuals with diabetes are not benefiting from NE programmes. Some of the reasons for this include: culturally incompatible programmes (Anderson-Loftin et al. 2002:247; Brown et al. 2005:527), programmes that only target knowledge transfer and those that do not actively involve the patients (Clement 1995:1205; Knight, Dornan \& Bundy 2006:495). The problem may further be compounded by the fact that, when compared with other diabetes self-management areas, dietary self-management is noted to be the most difficult (AndersonLoftin et al. 2002:247; Glasgow et al. 1997:558). This is particularly apparent among low-income groups (Cox et al. 2004:163).

Diabetic individuals from resource-poor settings are also faced with unique issues that may limit their ability to benefit from education programmes. They have a higher prevalence of low literacy, which poses a challenge to the appropriate understanding of diabetes and its management (Eakin et al. 2002:27). Language barriers may contribute to a lack of motivation to seek appropriate health care (Anderson-Loftin et al. 2005:556; Glazier et al. 2006:1675). Low income levels and limited access to transport hinder their access to continuous quality care (Cox et al. 2004:29; Eakin et al. 2002:18; Glazier et al. 2006:29). Cultural beliefs may also mitigate against taking on a greater role in selfcare (Eakin et al. 2002:18; Glazier et al. 2006:29). Therefore, they may experience more barriers to self-managed care than their counterparts in higher socio-economic settings.

Given that educating patients to better manage their diabetes is a feasible strategy due to low technical complexity, low capital requirements and cultural adaptability (Narayan et al. 2006:175), effective NE programmes could be utilised to bring about the desired outcomes in diabetics. This, consequently, would reduce diabetes-related complications and the associated socioeconomic burden, which is of particular concern in resourcepoor settings.

To design effective nutrition education programmes for diabetic individuals from resource-poor settings, it is essential that the developers be knowledgeable about those characteristics that contribute to a successful programme. In this review we define a resource-poor setting as a geographical location with limited infrastructure (facilities and services) and a population with low income. Although several interventions have been implemented in resource-poor settings, there is a lack of consolidated data on the factors that specifically contribute to the effectiveness of nutrition education programmes. The main objective of this article was to review published reports on nutrition education interventions in diabetes care since 1995. The specific objectives were:

- to identify the elements that contribute to an effective nutrition education programme for adults with diabetes in resource-poor settings, and

- to provide guidance to health professionals intending to plan NE programmes for diabetic populations in resourcepoor settings.

The methods for finding the selected material included the use of the databases Medline, PubMed and Cumulative Index to Nursing and Allied Health (CINAHL), which were searched for the terms effectiveness, nutrition education, dietary intervention, self-management education, type 2 diabetes, low-income, and resource limited/poor setting. Studies were included if they involved adult participants diagnosed with type 2 diabetes and dietary intervention, if the outcomes were reported and if the articles had been published between 1995 and the present date (November 2008). Only articles in English and those that used human participants were included. The samples were not restricted to any continent. Review articles that met the criteria were also included.

\section{An effective nutrition education programme}

An effective NE programme achieves the desired goals and outcomes that relate to an appropriate change in dietary behaviour (Contento, Randell \& Basch 2002:12). An appropriate change in dietary behaviour is reflected in healthy food choices and eating habits (Contento et al. 2002:12; PADA 1996:1184). The primary outcome expected from this change is improved glycaemic control (ADA 2007b:48; Pastors et al. 2003:827). Other desirable outcomes include improved lipid profile, blood pressure and body weight (ADA 2007b:48; Pastors et al. 2003:827). Potential mediating factors, including knowledge, attitudes and skills related to diabetes and diet, are also expected to improve (Peyrot 1999:64-5).

\section{Active involvement of the learner/patient}

The responsibility for diabetes care lies primarily with the individual with diabetes (Anderson \& Funnel 2000:597). To acquire the knowledge, skills and attitudes necessary for appropriate self-care behaviours, including diet, he/she needs to be actively involved in the learning and decision-making processes. The active involvement of the learner has been shown to be more effective in improving diabetes self-management outcomes than the didactic teaching approach (Elasy et al. 2001:125; Glazier et al. 2006:1687; Knight et al. 2006:498; Norris et al. 2001:583).

Strategies that actively engage the learner in the learning and decision-making processes in diabetes education include handson activities such as meal preparation (Anderson-Loftin et al. 2002:249; Rosal et al. 2005:227; Trento et al. 2001:996), collaborative goal setting and problem solving (Peyrot \& Rubin 2007:2435; Rosal et al. 2005:228), cognitive reframing (Ellis et al. 2004:103; Rosal et al. 2005:228), group discussions (Anderson-Loftin et al. 2002:249; Banister et al. 2004:807; Trento et al. 2001:24), story telling (Anderson-Loftin et al. 2002:249) and role playing (Trento et al. 2001:996).

\section{Behaviour-focused approach based on appropriate theories/models}

Research indicates that the correlation between knowledge and behaviour change is low (Clement 1995:1205; Day 2000:73; Norris et al. 2001:580), and that education programmes that incorporate behaviour change strategies are more effective in changing behaviour (Brown 1999:52; Campbell et al. 1996:379; Clement 1995:18; Contento et al. 2002:12;). Therefore, nutrition education programmes for individuals with diabetes must go beyond knowledge, and target dietary and other nutritionrelated behaviours. 


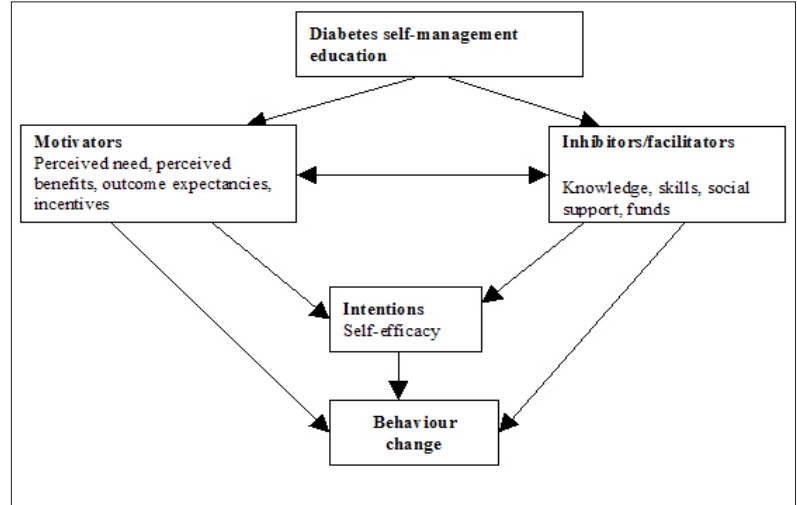

FIGURE 1

Conceptual framework of the relationships between factors of behaviour change targets in diabetes interventions. Based on factors of targets in diabetes interventions by Peyrot and Rubin (2007:2437)

The factors that should be targeted to help individuals change their dietary and other health behaviours include psychosocial factors that are antecedents of behaviour, such as personal factors (attitudes and beliefs), behavioural capabilities (knowledge and skills) and environmental factors that facilitate or impede change (Contento et al. 1995:326). Peyrot and Rubin (2007:2434) have suggested targeting the following factors in diabetes interventions:

- Motivators (factors that predispose one to action, such as perceived need, perceived benefits of treatment, outcome expectancies, rewards/incentives and cues to action)

- Inhibitors/facilitators (barriers such as a lack of funds, skills and support or resources for action)

- Intentions (proximal cause of behaviour change, i.e. individuals must have an intention to change, be ready to change and have a goal towards which they can work)

- Triggers (events that shift a person from being predisposed to action into an action state). (Figure 1 shows a framework of these factors).

Behaviour change is a complex process. Therefore, a theoretical foundation is recommended for planning behaviour intervention programmes (Anderson, Funnel \& Hernandez 2005:515; Fischer \& Glasgow 2007:2433; Knight et al. 2006:498). Theory facilitates our understanding of the relationships that exist between the factors that influence behaviour change (Anderson et al. 2005:518; Chapman et al. 1995:27; McKenzie, Neiger \& Smeltzer 2005:147148). The appropriate use of education and behaviour theory helps to ensure congruence between the planned interventions and the expected outcomes (McKenzie et al. 2005:145-146).

The most commonly used theories in diabetes education include the Health Belief Model (HBM), the Theory of Planned Behaviour (TPB), Socio-Cognitive Theory (SCT) and the Trans-Theoretical Model (TTM). The HBM (Rosenstock, Strecher \& Becker 1988:15) emphasises perceived threat as a motivating force and perceived benefits (fewer barriers) as providing a preferred path to action. The HBM, as applied to dietary adherence for diabetes management, includes beliefs about personal susceptibility to the secondary complications of diabetes, the severity of diabetes and its complications, the belief that dietary adherence will render benefits in preventing the complications, the perception that barriers and other costs related to dietary adherence are not excessive, and that individuals have the ability to make the recommended dietary changes (Chapman et al. 1995:75).

The TTM (Prochaska \& Velicer 1997:38-48) views behaviour change as a process in which the individual progresses through a series of six distinct stages of change. To successfully use this model, it is necessary to identify the participant's stage and then match the offered education to that stage. Ruggiero (2000:13) has discussed the application of TTM in diabetes, providing guidelines for assessment and behaviour change interventions for diabetes care. The model was utilised in a randomised controlled trial to distinguish the diabetes-related characteristics of individuals at different stages of change towards healthier, low-fat diets (Vallis et al. 2003:1469). In this study, overweight individuals with type 2 diabetes identified to be in the action stages (action and maintenance) had healthier eating behaviours than those in the pre-action stages (pre-contemplation, contemplation and preparation) (Vallis et al. 2003:1472).

The SCT (Bandura 2001:52) describes learning as a reciprocal interaction between an individual's cognitive processes, the environment and behaviour (reciprocal determinism). This is the basis for including interventions at the level of both the environment and the individual. The model has several constructs, but those commonly applied in diabetes include reinforcement (Miller et al. 2002:254), behaviour capability (knowledge and skills necessary to perform a behaviour) (Miller et al. 2002:254) and self-efficacy (confidence in one's ability to successfully perform a specific behaviour) (Garret $e t$ al. 2005:321).

The TPB is an extension of the Theory of Reasoned Action (TRA) (McKenzie et al. 2005:152-153). The TRA states that an individual's intention to perform a given behaviour is a function of his/her attitudes toward performing the behaviour and the normative beliefs about what relevant others think they should do, weighted by the motivation to comply with those others. Perceived behavioural control, the additional concept in PTB, asserts that behavioural intent and behaviour are also influenced by the degree of control people feel they have over circumstances, or in being able to perform a given behaviour. The more favourable the attitude and subjective norm with respect to a behaviour and the greater the perceived degree of control, the stronger the individual's intentions to perform the behaviour (McKenzie et al. 2005:152-153). Chapman et al. (1995:25) applied the TPB theory to older diabetic adults. They found that the intention to consume certain high-fat foods was strongly related to subjective norms, attitudes towards dietary adherence and perceived control.

\section{Appropriate medium of delivery and group/ individual settings}

Education programmes could be delivered using a face-toface approach, written material, the telephone and electronic methods. The face-to-face method is used most commonly (Ellis et al. 2004:103; Knight et al. 2006:486) and the one associated with better health outcomes in DSME programmes (Ellis et al. 2004:103; Warsi et al. 2004:1646), even among disadvantaged populations (Glazier et al. 2006:1687).

Individual and group approaches have both been used in diabetes patient education in almost equal frequencies (Elasy et al. 2001:124). However, very few studies have directly compared the effectiveness of group versus individual formats for delivering a specific intervention. Rickheim et al. (2002:272), in a randomised controlled trial comparing the effectiveness of the two approaches, observed that both approaches showed improvements in body weight, psychosocial adjustments, mental health and attitudes towards diabetes and glycaemic control, but with a slightly more marked reduction in $\mathrm{HbA}_{1 \mathrm{c}}$ in the group setting. Another randomised controlled trial comparing group education versus individual consultations delivered as routine diabetes care in type 2 diabetics observed that, after two years, the group participants had better health outcomes. They had sustained their levels of $\mathrm{HbA}_{1}$, while the levels of those in individual settings had worsened. The individuals in group setting also had increased HDL cholesterol levels and had reduced their body mass index (BMI) and triglyceride levels (Trento et al. 2001:999).

A systematic review of randomised controlled trials showed that group delivery was more effective for lifestyle programmes 
(interventions focusing on diet and physical activity) (Norris et al. 2001:583). However, group versus individual delivery was found not to be a statistically significant predictor of glycaemic control in a meta-analysis by Norris et al. (2002:1164). Clement's review of DSME (1995:1208) observed that small groups and one-on-one education might be equally effective in enhancing self-care behaviours and glycaemic control, and suggests that an optimum programme is one that uses both formats. Brown (1999:56-7) concluded that a combination of the two approaches achieved higher knowledge gains in diabetes self-management programmes and supported the use of small groups of ten participants or fewer.

A combination of the above-mentioned approaches could provide more benefits than those offered by either alone. Group processes encourage changes in beliefs and values as members share their knowledge, beliefs and skills and use the experience of others as a model (Garret et al. 2005:322; Maldonato et al. 1995:61). In a group setting, individuals can obtain emotional support from people with similar experiences (Garcia \& Suarez 1996:29; Van der Ven 2003:16). Group education is also cost effective and efficiently utilises scarce resources (Mensing \& Norris 2003:16; Wilson 1997:32). One-on-one education allows better tailoring to each individual's needs and better interaction based on nonverbal signals (Maldonato et al. 1995:61; Wilson 1997:70). It is useful in exploring long-term intrapersonal problems (Van der Ven, 2003:88) or in initial education, when educational objectives need to be strictly selected, especially in the presence of severe emotional distress (Maldonato et al. 1995:61).

Wilson (1997:71) has suggested using telephone contacts to follow up on progress and to provide individual counselling after or in between group sessions as a way of combining the two methods. The latter is more feasible in resource-poor settings. A combination of the two approaches was utilised in a DSME pilot programme for low-income Spanish-speaking patients in which the majority of the sessions were dedicated to the group format. The study observed significant improvements in glycaemic control at three and six months (Rosal et al. 2005:331).

\section{Tailored intervention}

Education programmes must be matched to the needs and abilities of the patient (Clement 1995:1210; PADA 1996:1184; Fischer \& Glasgow 2007:2746) if they are to be effective. Messages and materials that are customised to address the unique needs and concerns of specific patients have been shown to be effective in changing health-related behaviour (Clark 2002:183-4; Kreuter \& Strecher 1996:103).

To design a targeted education programme, a needs assessment is recommended (Eakin et al. 2002:28; PADA 1996:1183-1184; Rosal et al. 2005:227). This exercise helps to provide a better understanding of the target group in terms of aspects such as knowledge, attitudes, barriers and facilitators to behaviour change, needs and preferences for diabetes education (PADA 1996:1183-4; Rosal et al. 2005:227).

Different methods can be used to conduct a needs assessment (McKenzie et al. 2005:72-83). However, the use of focus groups has been a major strategy in developing or adapting selfmanagement interventions, especially in low-income and minority groups (Benavides-Vaello et al. 2004:238; Blanchard et al. 1999:919; Brown, Garcia \& Winchell 2002:168). The informal style of focus groups is conducive to identifying barriers to care, exploring health beliefs, identifying education needs and gathering information to improve intervention programmes (Benavides-Vaello et al. 2004:238). The synergy promoted by the group interaction produces ideas and statements that would not be generated with other types of methods. Respondents can qualify, clarify and build upon responses, thus conveying more thoughtful and in-depth information (Betts, Baranowski \& Hoerr 1996:280; Blanchard et al. 1999:919).

\section{Needs/abilities that need special consideration Literacy levels}

A high proportion of low-income populations have low literacy levels (Anderson-Loftin et al. 2002:248; Rosal et al. 2005:226), therefore the content of the education programme should be simple so as to increase comprehension and compliance (Anderson-Loftin et al. 2002:249; Brown 1999:231; Rosal et al. 2005:226; Ziemer et al. 2004:1719).

Strategies and educational materials that enhance understanding should be incorporated, e.g. the use of visual materials, actionoriented teaching, repetition of key concepts and skills, facilitation of frequent timely feedback (Rosal et al. 2005:226) and the practice of focusing on a few dietary concepts at a time (AndersonLoftin et al. 2005:557). Other strategies include minimal reading activities, such as group discussions, demonstrations, video shows (Brown et al. 2002:168) and visits to real-world settings such as grocery stores ( Brown et al. 2002:261; Mensing \& Norris 2003:99).

\section{Socio-cultural context}

Attitudes and beliefs about foods tend to reflect cultural values. Cultural food practices not only affect taste preferences, but also shopping habits, manners, communication and personal interactions (Nestle et al. 1998:51). Family and friends provide a source of modelling and peer pressure for consuming particular foods or trying new foods (Nestle et al. 1998:51). Therefore, consideration of the socio-cultural context of the target group/ patient is very crucial to increasing programme acceptance and effectiveness (Eakin et al. 2002:34).

Several studies have demonstrated that culturally sensitive interventions are effective in improving glycaemic control and dietary behaviours (Anderson-Loftin et al. 2002:245; Anderson-Loftin et al. 2005:560-562; Brown \& Hanis 1999:25; Brown et al. 2002:259). Aspects that have been used in diabetes patient education to increase cultural relevance include using the patient's preferred language, integrating cultural dietary preferences into healthy dietary strategies, integrating cultural traditions associated with food, such as family gatherings, incorporating family members (Anderson-Loftin et al. 2002:249; Brown et al. 2005:528), using ethnic food models to teach meal planning (Anderson-Loftin et al. 2002:249; Anderson-Loftin et al. 2005:557; Brown \& Hanis 1999:231), using culturally familiar experiences such as drama (Rosal et al. 2005:227), and having open, non-judgmental discussions about health beliefs and practices (Brown et al. 2005:528).

\section{Locality}

Patients with low incomes and low educational attainment tend to have low education programme attendance rates (Corkery et al. 1997:257; Noel et al. 1998:896) and high attrition rates (Corkery et al. 1997:257). Therefore, programme planners should incorporate aspects that enhance participation. A programme in a convenient locale that is easily accessible by public transport is crucial to solving the transport problem that is often cited as a barrier to participation in a programme (Eakin et al. 2002:27). Community settings such as schools, churches and community centres could be utilised as a strategy to overcome the socio-economic barriers to participation (Brown et al. 2002:168). These settings may be more convenient for and familiar to the participants (Brown et al. 2002:261) and their use is becoming more common, especially in under-served communities (Anderson-Loftin et al. 2002:528; Brown \& Hanis 1999:230; Brown et al. 2002:168).

\section{Appropriate nutrition education content and approach}

The content of the NE should be based on assessed individual/ group needs (Funnel et al. 2008:99). In newly diagnosed individuals, initial self-management education (survival skills) is necessary. This includes basic meal planning and exercise 
guidelines, signs and symptoms and prevention of hypoglycaemia for those on medication, nutritional management during short illnesses and blood glucose monitoring (Franz 2004:814-815). Thereafter, the topics/content that are emphasised should be based on the patient's lifestyle, level of nutrition knowledge, and experience in planning, purchasing and preparing meals. Suggested essential nutrition education topics include, among others, sources of carbohydrates, proteins and fats; nutrition labels; modification of fat intake; grocery shopping guidelines; guidelines for eating out and for special occasions; behaviour modification techniques; and tips for solving problems (Franz 2004:801-815). Appropriate meal planning approaches that enhance motivation and adherence to the diet are necessary (Franz 2004:823). The plate model, a visual approach to planning meals (Camelon et al. 1998:98), has been shown to improve the understanding of meal planning principles and the ability to plan healthy meals in individuals with type 2 diabetes in under-served populations (Raidil et al. 2007:4). This approach to meal planning could be useful in resource-poor settings, as it is simple, versatile and promotes understanding and memory retention (Camelon et al. 1998:98).

\section{Provision of social support}

Social support is an important element in dietary behaviour change (Adamson \& Mathers 2004:541; Sherman et al. 2000:209). Social interactions can provide good models for healthy eating, and feedback that can reinforce or modify one's self-evaluation. Peers, family and professionals can provide emotional support as well as challenge a patient's stereotypes or negative expectations regarding the proposed change (Adamson \& Mathers 2004:541; Nestle et al. 1998:51). Social persuasion helps to enhance confidence in individuals, and can assist diabetic individuals to improve their self-care behaviours (Lorig 2003:41). A study by Mau et al. (2001:1773) concluded that incorporation of social support (family member or friend) in an education program for individuals with diabetes or at risk of diabetes increased the likelihood of progressing from pre-action to action/maintenance stage for dietary fat intake and exercise. The study also concluded that individuals who advanced to action/maintenance stage had healthier dietary and exercise behaviours.

\section{Suitable programme duration and contact time}

There is very little guidance in the literature on the appropriate dosage (length and contact time) for diabetes education interventions. A few studies, however, do point to the fact that sufficientduration and contact time arenecessary for a programme to be effective. A meta-analysis by Norris et al. (2002:25) showed that $\mathrm{HbA}_{1 \mathrm{c}}$ levels decreased with increased contact time between the participant and the educator. Similarly, in a study of dosage effects of diabetes education for Mexican Americans, Brown et al. (2005:527) found that individuals who attended more sessions showed greater improvement in metabolic control. In another study, the same authors observed a maximum benefit effect of self-management education on glycaemic control at six months for Mexican Americans (Brown et al. 2002:265). A systematic review by Glazier et al. (2006:1687) concluded that interventions for the socially disadvantaged, including low-income groups, should be of high intensity ( $>10$ contact hours) and delivered over a long duration ( $\geq 6$ months).

\section{Provision of follow-up intervention}

The maintenance of outcomes in individuals with diabetes is a challenge, and more so in minority groups and those with a low income (Eakin et al. 2002:32). In the meta-analysis by Norris et al. (2002:1159), the benefits of DSME were found to decline one to three months after the intervention. It therefore seems that follow-up intervention is necessary to maintain the achieved outcomes (Clement 1995:1208; Norris et al. 2001:563; Norris et al. 2002:1164). Additional group sessions at periodic intervals to reinforce previously learned self-management information and

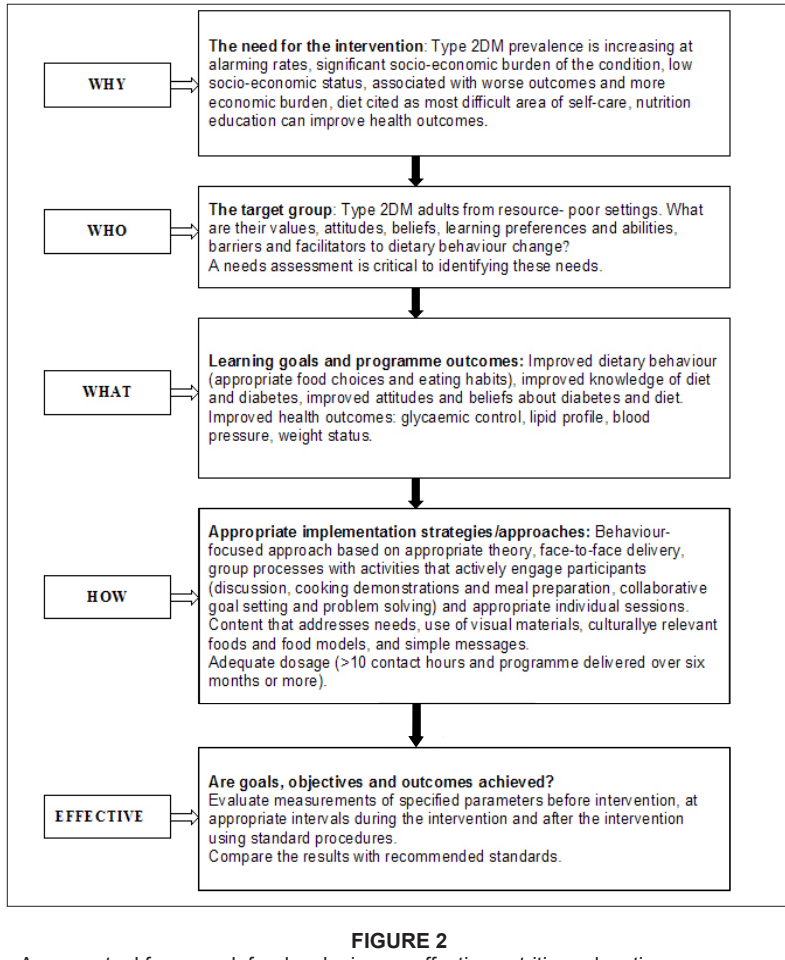

A conceptual framework for developing an effective nutrition education programme for adults with type 2 diabetes mellitus in resource-poor settings. Adapted from Murphy (2004:191)

to provide social support are a feasible option in resource-poor settings (Brown et al. 2002:169).

\section{Competent educator}

An effective NE programme is a programme that is delivered by a competent educator (Mensing \& Norris 2003:99; PADA 1996:1186). Characteristics of personal competency of successful nutrition educators include strong skills in interpersonal relationships, communication and listening, and interviewing skills (Knight et al. 2006:498; PADA 1996:1186), as well as skills in facilitating behaviour change (Fischer \& Glasgow 2007:30; Mensing et al. 2007:97). In addition, the basic competencies of a dietetic/nutrition professional are also necessary. These include an understanding of the fundamentals of the food and nutrition sciences, knowledge of the physiological and psychological determinants of eating behaviour, and an understanding of the environmental and social implications of the food system (PADA 1996:118). A registered dietician is the professional who is recommended to conduct nutrition education for individuals with diabetes (Mensing et al. 2007:97; Wilson et al. 2003:2500). However, in resource-poor settings, this professional category is often not adequate or available. Therefore, other health professionals should be trained to offer nutritional education (IDF 2005:22-25). Trained peer educators could also be utilised to deliver the education (Mau et al. 2001:1171; Two-Feathers et al. 2005:1552).

Table 1 summarises the elements that contribute to effective diabetes education, including MNT, derived from the reviewed studies. A conceptual framework of the factors that must be considered when planning an effective nutrition education programme for adults with diabetes mellitus in resource-poor settings is shown in Figure 2.

\section{CONCLUSION}

The results of this review indicate that effective nutrition education interventions for diabetic adults in resource-poor settings are those that address their unique needs and abilities. 
TABLE 1

Summary of elements of effective nutrition education in adults with type 2 diabetes mellitus in resource-poor settings

\begin{tabular}{|c|c|c|c|c|}
\hline TYPE OF INTERVENTION & SAMPLE & SETTINGS/INTERVENTION & KEY OUTCOMES & EFFECTIVE ELEMENTS (S) \\
\hline \multicolumn{5}{|l|}{ META-ANALYSIS/REVIEWS } \\
\hline Eakin et al., 2002 & $\begin{array}{l}15 \text { studies } \\
(1987-2001)\end{array}$ & $\begin{array}{l}\text { Low-income/minority } \\
\text { DSME including MNT }\end{array}$ & $\begin{array}{l}\text { Efficacy } \\
\text { Reach, implementation } \\
\text { and maintenance }\end{array}$ & $\begin{array}{l}\text { Needs assessment } \\
\text { Convenient locality }\end{array}$ \\
\hline Glazier et al., 2006 & $\begin{array}{l}17 \text { studies } \\
(1986-2004)\end{array}$ & $\begin{array}{l}\text { Low socio-economic status } \\
\text { Minority groups } \\
\text { Industrialized countries } \\
\text { RCT } \\
\text { DSME including MNT }\end{array}$ & $\begin{array}{l}\text { Clinical outcomes } \\
\text { Self-management } \\
\text { Provider management }\end{array}$ & $\begin{array}{l}\text { Tailored interventions } \\
\text { Trained educator } \\
\text { Behaviour change focused } \\
\text { Active patient participation } \\
\text { Addresses socio-cultural context } \\
\text { High-intensity interventions } \\
\text { Needs assessment } \\
\text { Face-to-face delivery } \\
\text { One-on-one education }\end{array}$ \\
\hline \multicolumn{5}{|c|}{ RANDOMISED CONTROLLED TRIALS (RCT) } \\
\hline Brown \& Hanis, 1999 & $\begin{array}{l}\mathrm{n}=247 \\
\text { Mexican-American } \\
\text { Low-income } \\
\text { Low literacy }\end{array}$ & $\begin{array}{l}\text { One-year intervention } \\
12 \text { weeks of group sessions } \\
14 \text { biweekly support sessions } \\
\text { DSME including MNT }\end{array}$ & $\begin{array}{l}\text { HbA1 } \text {, fasting blood glucose } \\
\text { Diabetes knowledge } \\
\text { Diabetes-related health beliefs } \\
\text { BMl, blood pressure } \\
\text { Total cholesterol }\end{array}$ & $\begin{array}{l}\text { Intensive intervention } \\
\text { Cultural appropriate } \\
\text { Community setting } \\
\text { Needs assessment } \\
\text { Minimal reading education materials }\end{array}$ \\
\hline Goldhaber-Fiebert et al., 2003 & $\begin{array}{l}\mathrm{n}=75 \\
\text { Low-income } \\
\text { Rural Costa Ricans }\end{array}$ & $\begin{array}{l}\text { Community based } \\
\text { Group nutrition and exercise } \\
\text { programme } \\
11 \text { weekly nutrition classes } \\
\text { (1.5 hours) } \\
\text { Tri-weekly walking groups } \\
\text { (1 hour) }\end{array}$ & $\begin{array}{l}\mathrm{HbA} 1_{c} \text {, fasting blood glucose } \\
\text { BMI, blood pressure } \\
\text { Total cholesterol } \\
\text { Triglycerides }\end{array}$ & $\begin{array}{l}\text { Community settings } \\
\text { Peer and family support } \\
\text { Offering classes at different time to } \\
\text { improve attendance } \\
\text { Culturally sensitive }\end{array}$ \\
\hline Rosal et al., 2005 & $\begin{array}{l}\mathrm{n}=25 \\
\text { Low-income Spanish }\end{array}$ & $\begin{array}{l}\text { Pilot study } \\
10 \text { weeks of group sessions } \\
\text { Two individual sessions } \\
\text { Community centre } \\
\text { DSME including MNT }\end{array}$ & $\begin{array}{l}\mathrm{HbA}_{1 \mathrm{c}} \text { lipid profile } \\
\text { Dietary intake } \\
\text { Self-monitoring of glucose }\end{array}$ & $\begin{array}{l}\text { Tailored messages } \\
\text { Intensive intervention } \\
\text { Repetition of key concepts } \\
\text { Family support } \\
\text { Using preferred language } \\
\text { Use of visual materials }\end{array}$ \\
\hline \multicolumn{5}{|l|}{ OTHER STUDY DESIGNS } \\
\hline Anderson-Loftin et al., 2002 & $\begin{array}{l}n=23 \\
\text { Rural African- } \\
\text { Americans } \\
\text { Low-income } \\
\text { Low literacy }\end{array}$ & $\begin{array}{l}\text { Quasi-experimental } \\
\text { (longitudinal) } \\
\text { Pilot study, five months } \\
\text { MNT- } 4 \text { low-fat classes, } 6 \\
\text { discussion groups } \\
\text { Follow-up (One home visit + } \\
\text { weekly telephone calls) }\end{array}$ & $\begin{array}{l}\text { Fasting blood glucose, } \mathrm{HbA} 1_{\mathrm{c}} \\
\text { BMI, blood pressure } \\
\text { Total cholesterol, triglycerides, Home } \\
\text { glucose monitoring } \\
\text { Dietary habits } \\
\text { Health services utilisation } \\
\text { Cost of care }\end{array}$ & $\begin{array}{l}\text { Experiential teaching methods } \\
\text { Group discussions } \\
\text { Culturally competent characteristics }\end{array}$ \\
\hline Anderson-Loftin et al., 2005 & $\begin{array}{l}\mathrm{n}=97 \\
\text { Rural African- } \\
\text { Americans } \\
\text { Low-income } \\
\text { Low literacy }\end{array}$ & $\begin{array}{l}4 \text { weeks MNT (low-fat dietary } \\
\text { strategies) } \\
\text { Five months of group } \\
\text { discussions } \\
\text { Weekly telephone follow-up }\end{array}$ & $\begin{array}{l}\text { BMI } \\
\text { Dietary behaviours }\end{array}$ & $\begin{array}{l}\text { Focusing on one dietary concept } \\
\text { Culturally competent characteristics } \\
\text { Experiential teaching methods }\end{array}$ \\
\hline Bannister et al., 2004 & $\begin{array}{l}\mathrm{n}=70 \\
\text { Low-income }\end{array}$ & $\begin{array}{l}\text { One group pre-test post-test } \\
\text { Community clinic } \\
\text { DSME including MNT } \\
\text { 4-hour group class plus } \\
\text { individual consultation by } \\
\text { dietician Monthly support } \\
\text { meetings }\end{array}$ & $\begin{array}{l}\mathrm{HbA1}{ }_{\mathrm{c}} \\
\mathrm{BMI} \\
\text { Medication } \\
\text { Costs }\end{array}$ & $\begin{array}{l}\text { Community site } \\
\text { Follow-up activities } \\
\text { Hands-on demonstrations } \\
\text { Family participation }\end{array}$ \\
\hline Brown et al., 2005 & $\begin{array}{l}\mathrm{n}=216 \\
\text { Mexican-American } \\
\text { Low income and } \\
\text { literacy level }\end{array}$ & $\begin{array}{l}\text { Comparison of dosage effects } \\
52 \text { contact hours vs. } 26 \text { hours } \\
\text { Groups randomised, but no } \\
\text { control } \\
\text { DSME including MNT }\end{array}$ & $\begin{array}{l}\text { HbA1 }{ }_{\text {, }} \text { fasting blood glucose } \\
\text { Diabetes knowledge } \\
\text { Diabetes-related health beliefs } \\
\text { BMI, blood pressure } \\
\text { Total cholesterol } \\
\text { Triglycerides } \\
\text { Home glucose monitoring }\end{array}$ & $\begin{array}{l}\text { Attendance of more sessions with } \\
\text { extended version }\end{array}$ \\
\hline Two-Feathers et al., 2005 & $\begin{array}{l}\mathrm{n}=151 \\
\text { African-Americans } \\
\text { Latinos } \\
\text { Low SES }\end{array}$ & $\begin{array}{l}\text { Community setting } \\
\text { One group pre-test post-test } \\
\text { One group pre-test post-test } \\
\text { Delivered by trained } \\
\text { community residents }\end{array}$ & $\begin{array}{l}\text { Diabetes knowledge } \mathrm{HbA} 1_{c}, \mathrm{BMl} \\
\text { Dietary behaviours } \\
\text { Blood pressure, total cholesterol } \\
\text { Triglycerides } \\
\text { Home glucose monitoring }\end{array}$ & $\begin{array}{l}\text { Community site } \\
\text { Culturally tailored education materials }\end{array}$ \\
\hline Mau et al., 2001 & $\begin{array}{l}\mathrm{n}=147 \\
\text { Rural Hawaiians }\end{array}$ & $\begin{array}{l}\text { Community setting } \\
\text { Quasi-experimental } \\
\text { 6-month programme } \\
\text { Addressing lifestyle } \\
\text { behaviours } \\
\text { Delivered by trained peers }\end{array}$ & $\begin{array}{l}\text { Dietary behaviours (fat, fibre, calories) } \\
\text { Physical activity }\end{array}$ & $\begin{array}{l}\text { Culturally tailored } \\
\text { Family support } \\
\text { TTM model }\end{array}$ \\
\hline
\end{tabular}

RCT - Randomised controlled trial

BMI- Body mass index

SES - Socio-economic status 
Effective NE comprises certain key elements: these include addressing low literacy levels by use of visual materials; experiential teaching methods; repetition of key concepts; few dietary concepts at a time; and tailoring the education to the socio-cultural context. An intensive programme (> 10 contact hours and extended duration of $\geq$ six months), follow-up intervention and support from peers and family are also crucial elements. A convenient locality, such as a community setting, is also important for enhancing participation in NE programmes. Other elements that may not be unique to this population include the active participation of the learner, face-to-face delivery and the use of behaviour change techniques/theories.

Planners of NE programmes for individuals with diabetes in resource-poor settings must be sensitive to the unique needs of this population and plan interventions that address these needs. A comprehensive needs assessment will serve as a cornerstone for planning a tailored NE programme. The planners must also be clear on the goals and objectives of the programme, use appropriate implementation strategies/approaches, including a competent educator, and evaluate the programme for effectiveness at appropriate intervals.

This review has some limitations. The studies that met the inclusion criteria were few, and most of the studies were done in under-served low-income populations in the USA, thus it is not clear how these results relate to other resource-poor settings, particularly in developing countries. However, the results provide a base for planning NE education programmes for adults with type 2 diabetes in resource-poor settings.

\section{REFERENCES}

ADA (American Diabetes Association), 2007a, 'Clinical practice recommendations; Standards of medical care', Diabetes Care 30(suppl. 1), S4-S41.

ADA (American Diabetes Association), 2007b, 'Nutrition recommendations and interventions for diabetes: A position statement', Diabetes Care 30(suppl. 1), S48-S65.

Adamson, A.J. \& Mathers, J.C., 2004, 'Effecting dietary change', Proceedings of the Nutrition Society 63, 537-547.

Anderson, R.M. \& Funnel, M.M., 2000, 'Compliance and adherence are dysfunctional concepts in diabetes care', Diabetes Educator, 26(4), 597-604.

Anderson, R.M., Funnell, M.M. \& Hernandez, C.A., 2005, 'Choosing and using theory in diabetes education research', Diabetes Educator 31(4), 513-520.

Anderson-Loftin, W., Barnett, S., Sullivan, P., Bunn, P.S., Tavakoli, A., 2002, 'Culturally competent dietary education for southern rural African Americans', Diabetes Educator 28(2), 245-257.

Anderson-Loftin, W., Barnett, S., Bunn, P., Sullivan, P., Hussey, J., Tavakoli, A., 2005, 'Soul food light: Culturally competent diabetes education', Diabetes Educator 31(4), 555-563.

Asha, A., Pradeepa, R. \& Mohan, V., 2004, 'Evidence for benefits from diabetes education programs', International Journal of Diabetes in Developing Countries 24(4), 96-102.

Bandura, A., 2004, 'Health promotion by social cognitive means', Health Education and Behaviour 31(2), 143-146.

Banister, N.A., Jastro, S.T., Hodges, V., Gillham, B., 2004, 'Diabetes self-management training program in a community clinic improves patient outcomes at modest cost', Journal of the American Dietetic Association 104(5), 807-810.

Bell, R.A., Camacho, F., Goonan, K., Duren-Winfiel, V., Anderson, R.T., Konen, J.C \& Goff, D.C., 2001, 'Quality of diabetes care among low-income patients in North Carolina', American Journal of Preventive Medicine 21(2), 124-131.

Benavides-Vaello, S., Garci, A.A., Brown, S.A \& Winchell, M. 2004, 'Using focus groups to plan and evaluate diabetes selfmanagement interventions for Mexican Americans', Diabetes Educator 30(2), 238-256.

Betts, N.M., Baranowski, T.\&Hoerr,S.L.,1996, 'Recommendations for planning and reporting focus group research', Journal of Nutrition Education 28(5), 279-281.
Blanchard, M.A., Rose, L.E., Taylor, J., McEntee, M.A., Latchaw, L.L., 1999, 'Using focus groups to design a diabetes education program for an African American population', Diabetes Educator 25(6), 917-925.

Brown, S.A., 1999, 'Interventions to promote diabetes selfmanagement: State of art science', Diabetes Educator 25(6), S52-S61.

Brown, S.A. \& Hanis, C.L., 1999, 'Culturally competent diabetes education for Mexican Americans: The Starr County Study', Diabetes Educator 25(2), 226-236.

Brown, S.A., Kouzekanani, K., Garcia, A.A. \& Hanis, C.L., 2002, 'Culturally competent diabetes self-management education for Mexican Americans: The Starr Border Health Initiative', Diabetes Care 25(2), 259-268.

Brown, S.A., Garcia, A.A. \& Winchell, M., 2002, 'Reaching the under-served populations and cultural competence in diabetes education', Current Diabetes Reports 2, 166-176.

Brown, S.A., Garcia, A.A., Blozis, S.S., Winchell, M., Kouzekanani, K. \& Hanis, C.L., 2005, 'Dosage effects of diabetes selfmanagement education for Mexican Americans: The Starr County Border Health Initiative', Diabetes Care 28(3), 527532

Camelon, K.M., Handell, K., Jamsen, P.T., Ketonen, K.J., Kohtamaki, H.M., Makimatilla, S., Tormala, M \& Valve, R.H., 1998, 'The plate model: A visual method of teaching meal planning', Journal of the American Dietetic Association 98(10), 1155-1158.

Campbell, E.M., Redman, S., Moffitt, P.S. \& Sanson-Fisher, R.W., 1996, 'The relative effectiveness of educational and behavioural instruction programs for patients with NIDDM: A randomised trial', Diabetes Educator 22(4), 379-386.

Chapman, K.M., Ham, J.O., Liesen, P. \& Winter, L. ,1995, 'Applying behavioural models to dietary education of elderly diabetic patients', Journal of Nutrition Education 25, 75-79.

Chin, M.H., Zhang, J.X. \& Merrell, K., 1998, 'Diabetes in the African-American Medicare population: Morbidity, quality of care and resource utilization', Diabetes Care 21(7), 10901095.

Clark, M., 2002, 'Lifestyle self-management in patients with type 2 diabetes', Journal of Diabetes Nursing 6(6), 182-187.

Clement, C., 1995, 'Diabetes self-management education', Diabetes Care 18(8), 1204-1214.

Contento, I.R., Bronner, Y.L., Swadener, S.S., Lytle, L.A., Maloney, S.K., Olson, C.M., Balch, G.I., 1995, 'The effectiveness of nutrition education and implications for nutrition education policy programs and research: A review of research', Journal of Nutrition Education 27(6), 277-422.

Contento, I.R., Randell, J.S. \& Basch, C.E., 2002, 'Review and analysis of evaluation measures used in nutrition education intervention research', Journal of Nutrition Education and Behaviour 34, 2-25.

Corkery, E., Palmer, C., Foley, M.E., Schetchter, C.B., Frisher, L. \& Roman, S.H., 1997, 'Effect of a bicultural community health worker on the completion of diabetes education in a Hispanic population', Diabetes Care 20(3), 254-257.

Cox, R.H., Carpenter, J., Bruce, S.A., Poole, K.P. \& Gaylord, C.K., 2004, 'Characteristics of low-income African-American and Caucasian adults that are important in self-management of type 2 diabetes', Journal of Community Health 29(2), 155-170.

Day, J.L., 2000, 'Diabetic patient education: Determinants of success', Diabetes Metabolism Research and Reviews 16 (suppl. 1), S70-S74.

Eakin, E.G., Bull, S.S., Glasgow, L.E. \& Mason, M., 2002, 'Reaching those most in need: A review of diabetes selfmanagement interventions in disadvantaged populations', Diabetes Metabolism Research and Reviews 18, 26-35.

Elasy, T.E., Ellis, S.E., Brown, A. \& Pichert, J.W., 2001, 'Taxonomy for diabetes educational interventions', Patient Education and Counseling 43, 121-127.

Ellis, E.E., Speroff, T., Dittus, R.S., Brown, A., Pichert, J.W. \& Elasy, T.A., 2004, 'Diabetes patient education: A meta-analysis and meta-regression', Patient Education and Counseling 52, 97-105. 
Fischer, L.F. \& Glasgow, R.E., 2007, 'A call for more effectively integrating behavioural and social science principles into comprehensive diabetes care', Diabetes Care 30(10), 27462749 .

Franz, M.J., 2004, 'Medical nutrition therapy for diabetes mellitus and hypoglycaemia of non-diabetic origin', in L.K. Mahan \& S. Escott-Stump, Krause's food, nutrition and diet therapy, 11th edn., pp. 792-830, WB Saunders, Philadelphia.

Franz, M.J., Warshaw, H., Daly, A.E., Pastors, J. \& Bantle, J., 2003, 'Evolution of diabetes medical nutrition therapy', Postgraduate Medical Journal 79, 30-35.

Franz, M.J., Monk, A., Barry, B., McClain, K., Weaver, T., Cooper, C., Upham, P., Bergenstal, R. \& Mazze, R.S., 1995, 'Effectiveness of medical nutrition therapy provided by dietitians in the management of non-insulin dependent diabetes mellitus: A randomised controlled trial', Journal of the American Dietetic Association 95, 1009-1017.

Funnell, M.M., M.M., Brown, T.L., Childs, B.P., Haas, L.B., Hosey, G.M., Jensen, B., Maryniuk, M., Peyrot, M., Piette, J.D., Reader, D., Siminerio, L.M., Weinger, K. \& Weiss, M.A. 2008, 'National standards for diabetes self-management education', Diabetes Care 31(suppl. 1), S97-S104.

Gagliardino, J.J. \& Etchegoyen, G.R., 2001, 'A model education program for type 2 diabetes: A co-operative Latin American implementation study (PEDNID-LA)', Diabetes Care 24(6), 1001-1007.

Garcia, R. \& Suarez, L., 1996, 'Diabetes education in the elderly: A 5-year follow-up of an interactive approach', Patient Education and Counseling 29(1), 87-97.

Garret, N., Hageman, C.N., Sibley, S.D., Davern, M., Berger, M., Brunzell, C., Malecha, K \& Richards, S.W., 2005, 'The effectiveness of an interactive small group diabetes intervention in improving knowledge, feeling of control and behaviour', Health Promotion and Practice 6(3), 320-328.

Glasgow, R.E., Strycker, L.A., Hampson, S.E. \& Ruggiero, L., 1997, 'Personal-model beliefs and social-environmental barriers related to diabetes self-management', Diabetes Care 20(4), 556-560.

Glasgow, R.E., Toobert, D.J. \& Hampson, J.F., 1996, 'Effects of a brief office based intervention to facilitate dietary selfmanagement', Diabetes Care 19(8), 835-842.

Glasgow, R.E., Lachance, P.A., Toobert, D., Hampson, S.E. \& Riddle, M.C., 1997, 'Long term effects and cost of brief behavioural intervention for patients with diabetes delivered from the medical office', Patient Education and Counseling 32(3), 175-185.

Glazier, R.H., Bajcar, J., Kennie, N.R. \& Wilson, N.K., 2006, 'A systematic review of interventions to improve diabetes care in the socially disadvantaged populations', Diabetes Care 29(7), 1675-1688.

Goldhaber-Fiebert, J.D., Tristan, M.L., Goldhaber, S.N. \& Nathan, D.M., 2003, 'Randomised controlled community based nutrition and exercise intervention improves glycaemia and cardiovascular risk factors in type 2 diabetic patients in rural Costa Rica', Diabetes Care 26(1), 24-29.

Hampton, K.K., Bodansky, H.J. \& Stickland, M., 1998, 'Audit of an educational program for recently diagnosed type 2 diabetic patients', Practical Diabetes 15(6), 166-167.

IDF (International Diabetes Federation-Clinical Guidelines Task Force), 2005, 'Global guidelines for type 2 diabetes: Lifestyle management', Chapter 5, pp. 22-25, viewed 22 August 2007 from http//www.idf.org/webdata/docs/GGT2D $\% 2005 \% 20$ lifestyle\%20management.pdf.

Knight, K.M., Dornan, T. \& Bundy, C., 2006, 'The diabetes educator: Trying hard, but must concentrate more on behaviour', Diabetic Medicine 23, 485-501.

Kreuter, M.W. \& Strecher, V.J., 1996, 'Do tailored behaviour change messages enhance the effectiveness of health risks appraisal: Results from a randomised trial', Health Education Research 11, 97-105.

Lemon, C.C., Lacey, K., Lohse, B., Hubacher, D.O., Klawittter, B. \& Palta, M., 2004, 'Outcomes monitoring of health, behaviour and quality of life after intervention in adults with type 2 diabetes', Journal of the American Dietetic Association 104, 1805-1815.
Levetan, B.N., Levitt, N.S. \& Bonnici, F., 1997, 'Hyperglycaemic emergencies are a common problem', South African Medical Journal 87, 368-370.

Lorig, K., 2003, 'Self management education more than a nice extra', Medical Care 41(6), 699-701.

Maldonato, A., Bloise, D., Ceci, M., Fraticelli, E. \& Fallucca, F., 1995, 'Diabetes mellitus: Lessons from patient education', Patient Education and Counseling 26(1), 57-66.

Mau, M.K., M.K., Grove, S.G., Johnson, B., Curb, J.D., Serivo, R. \& Glanz, K., 2001, 'Mediators of lifestyle behaviour change in native Hawaiians', Diabetes Care 24(10), 1770-1773.

McKenzie, J.F., Neiger, B.L. \& Smeltzer, J.L., 2005, Planning, implementing and evaluating health promotion programs, 4th edn., pp. 72-83, 147-157, Pearson Education, San Francisco.

Mensing, C.R., Ladichak, A., Lam, B., Mangan, M., Boucher, J., Cypress, M., Weinger, K., Mulcahy, K., Barta, P., Hosey, G., Kopher, W., Norman, J., Tanja, J., Yauk, L., Wisdom, K. \& Adams, C., 2007, 'National standards for diabetes selfmanagement education', Diabetes Care 30 (suppl. 1), S96S103.

Mensing, C.R. \& Norris, S.L., 2003, 'Group education in diabetes: Effectiveness and implementation', Diabetes Spectrum 16(2), 96-103.

Miller, C.K., Edwards, L., Kissling, G. \& Sanville, L., 2002, 'Nutrition education improves metabolic outcomes among older adults with diabetes mellitus: Results from a randomised controlled trial', Preventive Medicine 34(2), 252259.

Murphy, B., 2004, 'Health education and communication strategies', in H. Keleher \& B. Murphy (eds.), Understanding health: A determinants approach, Oxford University Press, Melbourne.

Narayan, K.M.V., Zhang, P., Williams, D., Engelgau, M.M., Imperatore, G., Kanaya, A. \& Ramachandran, A., 2006, 'How should developing countries manage diabetes?' Canadian Medical Association Journal 175(5), 733-736.

Narayan, K.M.V., Gregg E.W., Fagot-Campagna, A., Engelgau, M.M., Vinicor, F., 2000, 'Diabetes, a common, growing, serious, costly and potentially preventable public health problem', Diabetes Research and Clinical Practice 50(suppl. 2), S77-S84.

Nestle, M., Wing, R., Birch, L., DiSogra, L., Drewnowski, A., Middletown, S., Sigman-Grant, M., Sobal, J., Winston, M. \& Economos, C., 1998, 'Behavioural and social influences on food choice', Nutrition Reviews 56(5), S50-S74.

Noel, P.H., Larme, A.C., Marsh, G., Correa, A. \& Pugh, J.A., 1998, 'Patient education choice in diabetes curriculum: Nutritional versus standard content for type 2 diabetes', Diabetes Care 21(6), 896-901.

Norris, S.L., Lau, J., Smith, S.J., Schmid, C.H. \& Engelgau, M.M., 2002, 'Self-management education for adults with type 2 diabetes: A meta-analysis of effect on glycaemic control', Diabetes Care 25(7), 1159-1171.

Norris, S.L., Engelgau, M.M. \& Narayan, K.M.V., 2001, 'Effectiveness of self-management training in type 2 diabetes: A systematic review of randomised controlled trials', Diabetes Care 24(3), 561-587.

PADA (Position of the American Dietetic Association), 1995, 'Cost effectiveness of medical nutrition therapy', Journal of the American Dietetics Association 95, 88-91.

PADA (Position of the American Dietetic Association), 1996, 'Nutrition education for the public', Journal of the American Dietetic Association 96(11), 1183-1187.

Pastors, J.G., Warshaw, H., Daly, A., Franz, M.J. \& Kulkani, K., 2002, 'The evidence for the effectiveness of medical nutrition therapy in diabetes management', Diabetes Care 25(3), 608-613

Pastors, J.G., Franz, M.J., Warshaw, H., Daly, A. \& Arnold, M.S., 2003 , 'How effective is medical nutrition therapy in diabetes care?' Journal of the American Dietetic Association 103(7), 827831.

Peyrot, M., 1999, 'Behaviour change in diabetes education', Diabetes Educator 25(6) suppl., 62-73. 
Peyrot, M. \& Rubin, R.R., 2007, 'Behavioural and psychosocial interventions in diabetes: A conceptual review', Diabetes Care 30(9), 2433-2439.

Prochaska, J.O. \& Velicer, W.F., 1997, 'The trans-theoretical model of health behaviour change', American Journal of Health Promotion 12, 38-48.

Raidil, M., Spain, K., Lanting, R., Lockard, M., Hohson, S., Spencer, M., Sant, L., Welch, J., Liddil, A. \& HartmanCunningham, M., 2007, 'The healthy diabetes plate', Preventing Chronic Disease; Public Health Research, Practice and Policy 4(1), 1-7.

Ramachadran, A., Ramachadran,S., Snehalatha, C.\&Murigesan, N., 2007, 'Increasing expenditure of health care incurred by diabetic subjects in developing countries: A study from India', Diabetes Care 30(2), 252-256.

Rickheim, P.L., Weaver T.W., Flader, J.L., Kendall, D.M., 2002, 'Assessment of group versus individual diabetes education', Diabetes Care, 25, 271-274.

Roper, N. A., Bilous, R.W., Kelly, W.F., Unwin, N.C. \& Connoly, V.M., 2001, 'Excess mortality in a population with diabetes and the impact of material deprivation: Longitudinal, population base', British Medical Journal 322(7299), 13891393.

Rosal, M.C., Olendzki, B., Reed, G.W., Gumieniak, O., Scavron, J. \& Ockene, I., 2005, 'Diabetes self-management among lowincome Spanish speaking patients: A pilot study', Annals of Behaviour Medicine 29(3), 225-235.

Rosenstock, I.M., Strecher, V.J. \& Becker, M.H., 1988, 'Social learning theory and the health belief model', Health Education Quarterly 15(2), 175-183.

Ruggiero, L., 2000, 'Helping people with diabetes change behaviour: From theory to practice', Diabetes Spectrum 13(3), 125.

Shabbidar, S., Fathi, B. \& Shirazifard, N.M., 2006, 'Effects of clinical nutrition education on glycaemic control outcomes in type 2 diabetes', International Journal of Diabetes for Developing Countries 26(4), 156-159.

Sherman, A.M., Bowen, D.J., Vitolins, M., Perri, M.G., Rosal, M.C., Sevick, M.A \& Ockene, J.K., 2000, 'Dietary adherence: Characteristics and interventions', Controlled Clinical Trials 21, 206S-211S.
Trento, M., Passera, P., Tomalino, M., Bajardi, M., Pomero, F. Allione, A., Vaccari, P., Molinatti, G.M \& Porta, M., 2001, 'Group visits improve metabolic control in type 2 diabetes: A 2 year follow-up', Diabetes Care 24(6), 995-1000.

Two-Feathers, J., Kieffer, E.C., Palmissano, G., Anderson, M., Sinco, B., Janz, N., Heisler, M., Spencer, M., Guzman, R., Thompson, J., Wisdom, K. \& Sherman, A.J., 2005, 'Racial and ethnic approaches to community health (REACH) Detroit partnership: Improving diabetes related outcomes among African American and Latino adults', American Journal of PublicHealth 95(9), 1552-1560.

Vallis, M., Ruggiero, L., Greene, G., Jones, L., Zinman, B., Rossi, S., Edwards, L., Rossi, J.S. \& Proschaka, J.O., 2003, 'Stages of change for healthy eating in diabetes', Diabetes Care 26(50), 1468-1474.

Van der Ven, N., 2003, 'Psychosocial group interventions in diabetes care', Diabetes Spectrum 16(2), 88-95.

Wang, J., Armour, T., Geiss, L.S \& Engelgau, M.M., 2005, 'Obesity and diabetes: Dual epidemics on the rise', Current Opinion in Endocrinology and Diabetes 12(2), 174-180.

Warsi, A., Wang, P.S., LaValley, M.P., Avorn, J. \& Solomon, D.H., 2004, 'Self management education programs in chronic disease: A systematic review and methodological critic of literature', Archives of Internal Medicine 16(15), 1641-1649.

Wild, S., Roglic, G., Green, A., Sicree, R. \& King, H., 2004, 'Global prevalence of diabetes: Estimates for the year 2000 and projections for 2030', Diabetes Care 27(5), 1047-1053.

Wilson, C., Brown, T., Acton, K. \& Gilliland, S., 2003, 'Effects of clinical nutrition education and educator discipline on glycaemic control outcomes in Indian health service', Diabetes Care 26(9), 2500-2504.

Wilson, S.R., 1997, 'Individual versus group education: Is one better?' Patient Education and Counseling 32, suppl., S67-S75.

Ziemer, D.C., Berkowitz, K.J., Panayioto, R.M., El-Kebbi, I.M., Musey, V.C., Wanko, N.S., Slocum, W., Bacha, G.M., Musey, V.C., Gallina, D.L., Cook, C.B., Fowke, M.L., Anderson, L.A., Philips, L.S., Brazier, C.W. \& Dunbar, V.G., 2003, 'A simple meal plan emphasizing healthy food choices is as effective as an exchange based meal plan for urban African American with type 2 diabetes', Diabetes Care 26(6), 1719-1724. 